\title{
PENILAIAN HARGA SAHAM TELEKOMUNIKASI MENGGUNAKAN PENDEKATAN RASIO KEUANGAN
}

\author{
Muliasari Pinilih ${ }^{1 *}$, Intan Shaferi ${ }^{2}$ \\ ${ }^{1} J u r u s a n$ Sistem Informasi, Fakultas IImu Komputer, Universitas Amikom Purwokerto, Indonesia \\ 2Jurusan Manajemen, Fakultas Ekonomi dan Bisnis, Universitas Jenderal Soedirman, Indonesia \\ *Email corresponding author: mpinilih@amikompurwokerto.ac.id \\ Diterima 19/10/2019 Direvisi 07/01/2020 Diterbitkan 31/01/2020
}

\begin{abstract}
Abstrak
Perkembangan teknologi informasi dan jaringan internet mampu menggerakan sektor telekomunikasi yang memiliki daya saing dibandingkan dengan sektor ekonomi lainnya. Hal ini berdampak pada saham telekomunikasi di BEI. Sebagai seorang investor dalam penentuan investasi akan melakukan analisis terlebih dahulu sebelum mengambil keputusan pembelian. Salah satu pendekatan analisis yang digunakan dengan melihat rasio keuangan. Rasio keuangan yang akan diteliti dalam penelitian ini adalah Current Ratio (CR), Earning Per Share (EPS), Debt On Equity Ratio (DER) dan Return On Assets (ROA) pada sektor telekomunikasi dengan periode 2014-2018. Metode analisis yang digunakan adalah regresi berganda untuk melihat pengaruh rasio keuangan terhadap harga saham telekomunikasi. Berdasarkan hasi analisis, didapatkan bahwa CR memiliki pengaruh secara parsial terhadap harga saham namun EPS, DER dan ROA secara parsial tidak mampu mempengaruhi harga saham. Hasil analisis secara simultan menunjukkan bahwa CR, EPS, DER dan ROA mampu mempengaruhi harga saham telekomunikasi.
\end{abstract}

Kata Kunci: Telekomunikasi, Harga, Saham, Rasio, Keuangan

\begin{abstract}
The development of information technology and the internet can boost the telecommunication industry. It makes the telecommunication industry has competitiveness than other sectors and has an impact on telecommunication shares on the Indonesian Stock Exchange. As an investor, they will conduct an analysis first, before making decisions to buy or not. One of the approaches used is financial ratio analysis. In this research, the financial ratio is the Current Ratio (CR), Earning Per Share (EPS), Debt On Equity Ratio (DER), and Return On Assets (ROA) of the telecommunications sector in 2014-2018. The analysis method in this study using multiple regression to see the effect of financial ratios on the telecommunication stock prices. Based on the result of the analysis, CR can effect to telecommunication stock prices. But, EPS, DER, and ROA unable to affect telecommunication stock prices. Simultaneously, CR, EPS, DER, and ROA had effect telecommunications stock prices.
\end{abstract}

Keywords:. Telecommunication, Price, Stock, Ratio, Financial 


\section{PENDAHULUAN}

Salah satu cara melakukan investasi adalah dengan membeli saham. Kepemilikan saham memberikan keuntungan berupa deviden bagi pemegang saham. Meskipun begitu, investor juga menyadari bahwa keuntungan yang tinggi sebanding pula dengan resiko yang didapatkan (Thrisye \& Simu, 2013). Untuk menghindari resiko dan mencari informasi dari saham terpilih maka ada kecenderungan investor akan melakukan beberapa analisis investasi. Analisis investasi ini bukan merupakan tugas yang mudah karena banyak aspek yang terlibat dalam pengambilan keputusan investasi saham. Indikator umum dalam investasi saham adalah pergerakan harga saham.

Pergerakan harga saham dipengaruhi oleh kondisi eksternal dan internal perusahaan sehingga kondisi ini menciptakan pergerakan yang fluktuatif (Agustina \& Sumartio, 2014). Padahal harga saham dianggap sebagai gambaran kondisi keuangan suatu perusahaan. Jika keuangan baik maka akan berdampak pada harga saham yang tinggi begitu pula sebaliknya. Hal ini yang mendasari para investor harus jeli dalam melakukan investasi dan merancang portofolio saham. Informasi dari kinerja keuangan perusahaan dapat dilakukan analisis fundamental keuangan dengan berfokus pada rasio keuangan (Baresa, Bogdan, \& Ivanovic, 2013). Rasio keuangan mampu menggambarkan kondisi perusahaan pada saat tertentu baik itu kekuatan maupun kelemahan dari kinerja keuangan perusahaan (Thrisye \& Simu, 2013). Umumnya rasio keuangan ini akan berdampak kepada harga saham dan mampu menjadi sinyal pertimbangan bagi para investor. Rasio keuangan banyak macamnya dan semua mampu menunjukkan pengaruhnya terhadap harga saham.

Beberapa penelitian menunjukkan hasil yang berbeda mengenai pengaruh rasio keuangan terhadap harga saham. Hasil penelitian Fitriah \& Sudirjo (2016) menunjukkan bahwa harga saham bisa dipengaruhi oleh Current Ratio, Total Assets Turnover, Return On Assets, Price Earning Ratio dan Devident Payout Ratio namun Debt to Equity Ratio tidak mampu mempengaruhi harga saham. Tanjung, Suhadak, \& Sudjana (2013) meneliti DER, ROA, PER dan EPS. Berdasarkan hasil analisis dicatatkan bahwa faktor tersebut mampu memberikan pengaruh terhadap harga saham. Suatu harga saham dapat dipengaruhi oleh rasio keuangan baik positif atau negatif.

Kondisi ini menarik untuk diteliti kembali tapi menggunakan rasio keuangan yang berbeda yaitu Current Ratio (CR), Earning per Share (EPS), Debt to Equity Ratio (DER) dan Return on Asset (ROA) serta obyeknya pada saham telekomunikasi. Industri telekomunikasi di Indonesia memiliki prospek yang semakin besar mengingat masifnya perkembangan teknologi komunikasi dan internet. Kebutuhan masyarakat yang mulai bergeser dikarenakan mobilitas yang tinggi serta kebutuhan akan akses informasi yang cepat mendorong pula industri telekomunikasi. Prospek ini menjadikan industri telekomunikasi menjadi salah satu industri yang mampu menunjukkan peningkatan signifikan dalam kapitalisasi pasar. Gambar 1 merupakan kapitalisasi pasar perusahaan telekomunikasi 2012 sampai 2016.

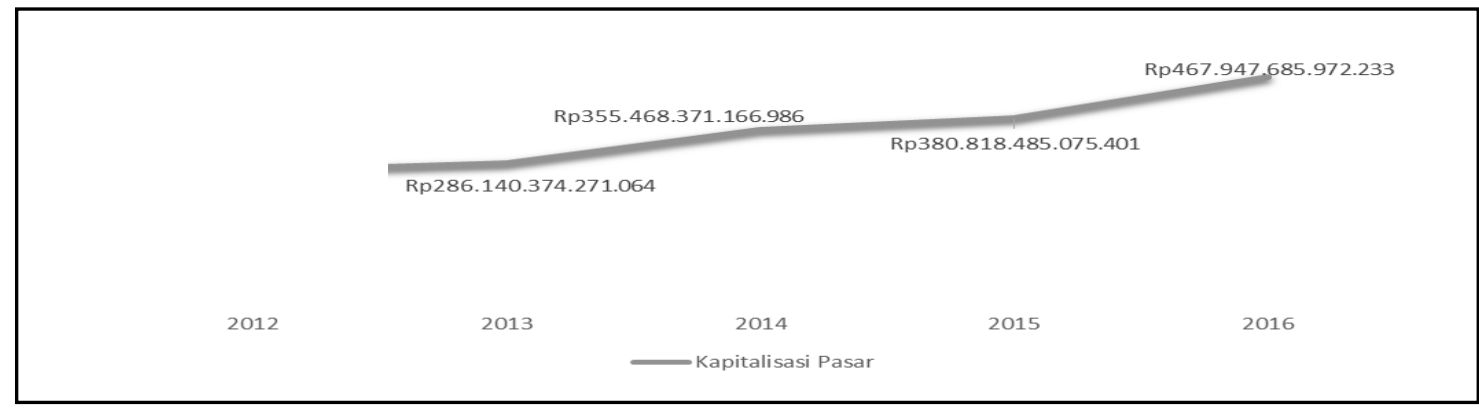

Sumber : idx

Gambar 1. Kapitalisasi Pasar Industri Telekomunikasi 2012-2016 


\section{PERFORMANCE}

Jurnal Personalia, Financial, Operasional,

Marketing dau Sistern Informasi

Performance. Volume 27 Nomor 1 Tahun 2020, 21-29

Nilai kapitalisasi pasar industri telekomunikasi yang semakin meningkat terlihat jelas pada periode 2012-2016 dan diperkirakan akan terus meningkat. Di tahun-tahun mendatang. Bahkan salah satu emiten industri telekomunikasi yaitu Telkom Indonesia Tbk tercatat dalam lingkup lima emiten dengan kaitalisasi pasar terbesar. Peningkatan ini menarik minat investor untuk melakukan investasi ke dalam industri telekomunikasi karena pada dasarnya investasi dilakukan untuk mendapatkan keuntungan yang optimal. Berdasarkan hal ini, penelitian akan berfokus pada menilai harga saham telekomunikasi dengan pendekatan rasio keuangan. Penelitian yang mengenai harga saham telekomunikasi pernah dilakukan oleh Megawati (2018) dengan menekankan pada rasio keuangan CR, DR, NPM, TATO dan PER. Penelitian yang akan dilakukan menggunakan saham pada industri telekomunikasi namun perbedaan penelitian akan ditekankan pada rasio keuangan yang berbeda. Selain itu, periode pengamatan pun memiliki rentang waktu yang berbeda yaitu penelitian ini menggunakan data terbaru yaitu tahun 2014-2018.

\section{TINJAUAN PUSTAKA DAN PERUMUSAN HIPOTESIS}

Analisis fundamental merupakan langkah-langkah penilaian nilai instrinsik saham pada bursa efek dengan memperkirakan kekuatan perusahaan berdasarkan historis laporan keuangan dan saat ini (Wafi, Hassan, \& Mabrouk, 2015). Fokus pada kinerja suatu perusahaan untuk menentukan harga saham merupakan inti analisis fundamental (Anung, Hidayat, \& Sulasmiati, 2016). Hal yang paling utama dalam analisis fundamental adalah rasio keuangan yang digunakan untuk membandingkan performa perusahaan sejenis atau yang memiliki ukuran yang sama. Masingmasing rasio keuangan memiliki tujuan, kegunaan dan dampak terhadap harga saham (Baresa et al., 2013).

Menurut Weston dalam Erica (2018) terdapat empat pembagian rasio keuangan, yaitu (a) Rasio Likuiditas (Liquidity Ratio), akan menunjukkan kewajiban jangka pendek yang sanggup dipenunuhi oleh perusahaan; (b) Rasio Solvabilitas (Leverage Ratio), indikator untuk mengukur aktiva perusahaan yang dibiayai utang di dalam perusahaan; (c) Rasio Aktivitas (Activity Ratio), rasio efisiensi penggunaan sumber organisasi; (d) Rasio Profitabilitas (Profitability Ratio), melihat bagaimana kecakapan organisasi untuk mencari profit; (e) Rasio Pertumbuhan (Growth Ratio), upaya organisasi dalam bertahan menghadapi tantangan dari sisi pertumbuhan ekonomi dan usaha sejenis; (f) Rasio Penilaian (Valuation Ratio), rasio yang menilai manajemen dari usaha mencetak nilai pasar lebih dari biaya investasi. Rasio keuangan yang diteliti untuk melihat pengaruhnya terhadap harga saham telekomunikasi sebagai berikut:

\section{Pengaruh Current Ratio (CR) terhadap harga saham}

Current Ratio (CR) rasio yang digunakan dalam mengukur tingkat likuiditas perusahaan. Semakin meningkat CR suatu perusahaan maka perusahaan tersebut dianggap mampu untuk melunasi kewajiban jangka pendeknya. Hal ini bisa menjadi pertimbangan para investor untuk membeli saham yang pada akhirnya secara tidak langsung harga saham yang meningkat (A. Pratama \& Erawati, 2014). Rasio-rasio ini pernah ditelaah oleh beberapa peneliti, salah satunya oleh Megawati (2018) yang sama-sama berfokus pada saham telekomunikasi. CR, DR, NPM, TATO dan PER dipilih menjadi variabel yang akan diteliti pengaruhnya kepada harga saham. Hasil menunjukkan bahwa CR, NPM dan TATO mampu menunjukkan sinyal positif dan signifikan untuk mempengaruhi pergerakan harga saham. Meskipun pengaruh positif terlihat untuk DR dan PER dalam regresi namun tidak memiliki dampak terhadap harga saham. Selain itu, penelitian lain juga membuktikan variabel CR mampu mempengaruhi harga saham LQ 45 (Fitriah \& Sudirjo, 2016). Berdasarkan hasil tersebut maka dapat disusun hipotesis sebagai berikut:

H1 : Harga saham telekomunikasi dipengaruhi oleh CR. 
Performance. Volume 27 Nomor 1 Tahun 2020, 21-29

\section{Pengaruh Earning Per Share (EPS) terhadap harga saham}

Earning Per Share (EPS) dijadikan dasar dalam pembagian laba bersih kepada para pemegang saham, sehingga EPS memiliki dampak dalam perubahan harga saham. Jika pengelolaan saham dengan baik maka nilai EPS juga akan meningkat (Nurfadillah, 2011). Hadiansyah \& Gunawan (2017) meneliti meliputi ROA, ROE, EPS, DER dan LDR saham perbankan pad indeks LQ 45 sebagai pendekatan fundamental dan pengaruh inflasi serta nilai tukar sebagai pendekatan makro. Perhitungan analisis menunjukkan bahwa harga saham perbankan dipengaruhi oleh ROA, EPS, DER, dan nilai tukar secara individu namun harga saham tidak dipengaruhi oleh inflasi, ROE dan LDR secara parsial. Bila keseluruhan variabel dianalisis pengaruhnya terhadap harga saham maka didapatkan bahwa harga saham perbankan bisa dipengaruhi oleh variabel-variabel tersebut. Penelitian lain yang diusung oleh Nurfadillah (2011) berpusat pada saham PT Unilever Indonesia Tbk. dan menggunakan EPS, DER, dan ROE sebagai variabel yang akan diteliti pengaruhnya terhadap saham. Tercatat hasil analisis secara parsial hanya EPS dan ROE yang dapat mempengaruhi harga saham PT Unilever Indonesia Tbk namun secara simultan tercatat bahwa harga saham dipengaruhi oleh EPS, DER dan ROE. Penelitian terdahulu membawa pada kesimpulan hipotesis :

H2 : EPS berpengaruh terhadap harga saham telekomunikasi.

\section{Pengaruh Debt to Equity Ratio (DER) terhadap harga saham}

Menurut Hadiansyah \& Gunawan (2017), Debt to Equity Ratio (DER) menggambarkan kemampuan pemilik menggunakan modalnya untuk melunasi hutang kepada pihak lain. Nilai DER yang meningkat mengindikasikan bahwa semakin rendah pendanaan yang disediakan pemegang saham. Artinya keadaan ini akan memberikan sinyal buruk kepada penanam modal. DER salah satu variabel yang diteliti dalam melihat pengaruhnya terhadap harga saham. Pratama, Azizah, \& Nurlaily (2019) mengambil pendekatan ROE, EPS, CR dan DER pada perusahaan di kelompok Jakarta Islamic Index. ROE dan EPS memiliki pengaruh namun CR dan DER tidak memiliki pengaruh ke harga saham. Hasil penelitian yang juga menemukan bahwa harga saham tidak dipengaruhi DER ditemukan juga pada penelitian Nurfadillah (2011). Hasil yang berbeda didapatkan oleh Hadiansyah \& Gunawan (2017) yang menunjukkan bahwa harga saham bisa dipengaruhi oleh DER. Hasil Hadiansyah \& Gunawan (2017) sesuai dengan teori bahwa DER akan dapat mempengaruhi pergerakan harga saham. Hipotesis yang akan diajukan adalah :

H3 : DER berpengaruh terhadap harga saham telekomunikasi.

\section{Pengaruh Return on Asset (ROA) terhadap harga saham}

Return on Asset (ROA) menunjukkan kemampuan perusahaan mengelola aktivitas investasinya untuk menghasilkan laba untuk perusahaan. Jika perusahaan mampu menghasilkan laba dengan tinggi maka investor semakin memberi sinyal positif. Hal ini berdampak pada kenaikan harga saham (Dwialesi \& Darmayanti, 2016). ROA menjadi variabel fundamental yang akan dianalisis dalam penelitian ini. ROA juga beberapa kali diteliti untuk melihat hubungan dengan harga saham. Fitriah \& Sudirjo (2016) dan Hadiansyah \& Gunawan (2017) menemukan bahwa harga saham dapat dipengaruhi oleh ROA secara signifikan. Kedua peneliti memaparkan hasil yang sama terkait ROA dan harga saham, dengan berfokus pada saham yang berbeda. Berdasarkan hal ini maka disimpulkan bahwa hipotesis :

$\mathrm{H} 4$ : Harga saham telekomunikasi dipengaruhi oleh variabel ROA. 
Jurnal Personalia, Financial, Operasional,

Marketing dau Sistern Informasi

Performance. Volume 27 Nomor 1 Tahun 2020, 21-29

Berdasarkan teori terkait dan perumusan hipotesis penelitian, maka desain penelitian akan digambarkan seperti Gambar 2.

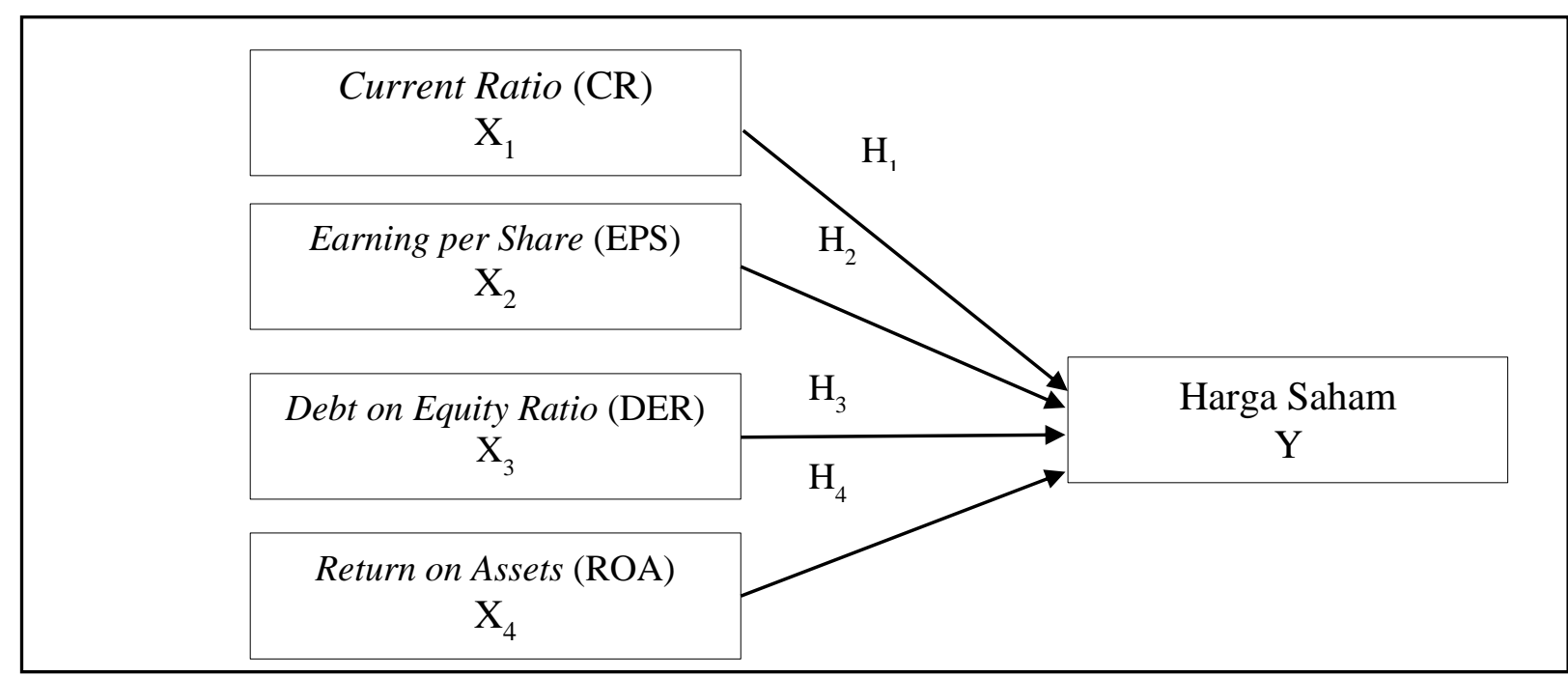

Gambar 2. Desain Penelitian

\section{METODE PENELITIAN}

Objek penelitian akan ditekankan pada saham lima perusahaan telekomunikasi pada periode 2014-2018. Penilaian harga saham ini akan direpresentasikan oleh rasio keuangan seperti Current Ratio (CR), Earning per Share (EPS), Debt to Equity Ratio (DER), dan Return on Asset (ROA). Data yang diperlukan guna menunjang penelitian merupakan data sekunder yang didapatkan dari Bursa Efek Indonesia (BEI). Metode analisis terhadap variabel tersebut menggunakan regresi berganda. Persamaan regresi yang akan didapatkan sebagai berikut (Basuki \& Prawoto, 2016) :

$Y^{\prime}=a+b_{1} X_{1}+b_{2} X_{2}+\cdots+b_{n} X_{n}$

Keterangan:

$\mathrm{Y}^{\prime} \quad=$ Variabel dependen (nilai yang diprediksikan)

$\mathrm{X} 1, \mathrm{X} 2$ dan $\mathrm{Xn}=$ Variabel independen

a $\quad=$ Konstanta

$\mathrm{b} \quad=$ Koefisien regresi

Penelitian melakukan pengujian hipotesis, hipotesis penelitian ini akan diuji menggunakan Uji t dan Uji F. Kriteria dalam pengambilan keputusan pada uji t akan membandingkan nilai signifikan dengan 0,05. Jika sig. > (lebih besar) 0,05 maka tidak ada pengaruh secara parsial dan jika sig. < (lebih kecil) 0,05 berarti terdapat pengaruh secara parsial. Untuk uji simultan atau uji F maka kriteria yang akan digunakan adalah signifikan yang lebih kecil 0,05 maka secara bersama-sama terdapat pengaruh begitu sebaliknya signifikan yang lebih besar dari 0,05 maka mengindikasikan secara bersama-sama tidak terdapat pengaruh (Bagiana, Putra, \& Sunarsih, 2016).

\section{HASIL DAN PEMBAHASAN}

Perhitungaan pengaruh rasio keuangan CR, EPS, DER dan ROA terhadap harga saham telekomunikasi 2014-2018 didapatkan bahwa variabel rasio keuangan yang dipilih memiliki nilai $R$ square sebesar 0,550. Nilai ini mencerminkan bahwa variabel CR, EPS, DER dan ROA mampu mempengaruhi variabel harga saham sebesar 55 persen dan sebesar 45 persen dipengaruhi oleh variabel yang tidak diteliti dalam penelitian. Hasil output R square dapat dilihat pada Tabel 1. 
Tabel 1. Model Summary

\begin{tabular}{|c|c|c|c|c|}
\hline \multicolumn{5}{|c|}{ Model Summary } \\
\hline Model & $\mathrm{R}$ & R Square & Adjusted R Square & $\begin{array}{l}\text { Std. Error of the } \\
\text { Estimate }\end{array}$ \\
\hline 1 & $.742^{\mathrm{a}}$ & .550 & .460 & 1.5376626 \\
\hline \multicolumn{5}{|c|}{ a. Predictors: (Constant), ROA, EPS, DER, CR } \\
\hline \multicolumn{5}{|c|}{ b. Dependent Variable: Price } \\
\hline
\end{tabular}

Hubungan antara variabel CR, EPS, DER dan ROA terhadap harga saham menghasilkan persamaan regresi $Y=4,568+0,029 C R+0,001 E P S+0,317 D E R+0,003 R O A$. Berdasarkan hasil regresi didapatkan bahwa variabel $C R$, EPS, DER, dan CR memiliki nilai yang positif sehingga mengindikasikan jika terjadi peningkatan dari salah satu variabel tersebut maka akan berdampak pula terhadap kenaikan harga saham. Hasil output regresi dapat dilihat pada Tabel 2.

Coefficients $^{\mathrm{a}}$

Tabel 2. Output Regresi

\begin{tabular}{|c|c|c|c|c|c|c|}
\hline \multirow{2}{*}{\multicolumn{2}{|c|}{ Model }} & \multicolumn{2}{|c|}{ Unstandardized Coefficients } & \multirow{2}{*}{$\begin{array}{c}\begin{array}{r}\text { Standardized } \\
\text { Coefficients }\end{array} \\
\text { Beta }\end{array}$} & \multirow[t]{2}{*}{$\mathrm{t}$} & \multirow[t]{2}{*}{ Sig. } \\
\hline & & B & Std. Error & & & \\
\hline \multirow[t]{5}{*}{1} & (Constant) & 4.568 & .829 & & 5.510 & .000 \\
\hline & $C R$ & .029 & .012 & .537 & 2.414 & .025 \\
\hline & EPS & .001 & .003 & .086 & .453 & .655 \\
\hline & DER & .317 & .234 & .255 & 1.353 & .191 \\
\hline & ROA & .003 & .009 & .065 & .291 & .774 \\
\hline
\end{tabular}

a. Dependent Variable: Price

Nilai a atau konstansta sebesar 4,568 mengindikasikan jika variabel CR, EPS, DER, dan ROA akan meningkatkan harga saham menjadi 4,568 satuan. Nilai koefisien CR sebesar 0,029 yang berarti akan terdapat kenaikan harga saham sebesar 0,029 jika nilai CR meningkat satu satuan. Koefisien EPS tercatat sebesar 0,001 dan bernilai positif yang berarti kenaikan satu satuan EPS maka akan meningkatkan harga saham sebesar 0,001 satuan. Koefisien DER sebesar 0,317 akan mengindikasikan adanya kenaikan harga saham sebesar 0,317 jika DER mengalami kenaikan. Pada ROA dengan nilai positif 0,003 menadakan bahwa ketika ROA meningkat maka berdampak pada peningkatan harga saham sebesar angka koefisien. Untuk membuktikan hipotesis maka akan merujuk pada nilai sig. di Tabel 2.

Masing-masing nilai sig. CR, EPS, DER dan ROA memiliki nilai berturut-turut 0,025; 0,655; 0,191; dan 0,774. Berdasarkan nilai sig. hasil analisis maka harga saham tercatat hanya secara parsial dan signifikan dipengaruhi oleh CR karena nilai sig CR yang lebih kecil dari 0,05. Hasil ini sekaligus mendukung $\mathrm{H}_{1}$ yang menyatakan terdapat pengaruh harga saham dan $\mathrm{CR}$. Bagi variabel lainnya seperti EPS, DER dan ROA secara parsial tercatat memiliki nilai sig. lebih besar dari 0,05 sehingga $\mathrm{H}_{2}, \mathrm{H}_{3}$ dan $\mathrm{H}_{4}$ ditolak yang artinya variabel tersebut tidak mampu memberikan pengaruh kepada harga saham. Variabel harga saham yang memiliki pengaruh terhadap CR menunjukkan hasil yang sama dengan penelitian Megawati (2018). CR menjadi signal yang akan dilihat investor dalam pembelian saham karena CR yang aman akan menarik minat investor sehingga mendorong peningkatan harga saham.

EPS juga menjadi sinyal bagi investor dalam memilih saham. Peningkatan EPS perusahaan menandakan pengelolaan modal yang baik sehingga berdampak pada kenaikan harga saham. 


\section{PERFORMANCE}

Jurnal Personalia, Financial, Operasional,

Marketing dau Sistem Informasi

Performance. Volume 27 Nomor 1 Tahun 2020, 21-29

Analisis hasil yang menunjukkan harga saham secara parsial tidak dipengaruhi oleh EPS ini bertentangan dengan hasil Hadiansyah \& Gunawan (2017) dan Nurfadillah (2011). Namun, hasil ini sesuai dengan Rahmadewi \& Abundanti (2018) dan Khairani (2016) yang menyatakan bahwa tidak berpengaruhnya EPS disebabkan investor tidak menggunakan fundamental analisis dalam pengambilan keputusan investasi dan hanya berdasarkan aspek pengalaman dan kebiasaan.

Variabel DER digunakan untuk melihat risiko perusahaan dan menjadi salah satu aspek yang diperhatikan dalam pengambilan keputusan berinvestasi. DER yang tinggi mencerminkan perusahaan tidak dalam keadaan sehat sehingga menyebabkan harga saham rendah (Fitriah \& Sudirjo, 2016). Hasil analisis regresi memperlihatkan harga saham telekomunikasi secara signifikan dan parsial tidak dipengaruhi oleh DER. Hasil yang didapatkan ini searah dengan hasil yang didapatkan Megawati (2018) dengan meneliti saham yang sama namun dalam periode waktu yang berbeda. Hasil yang tidak signifikan juga didapatkan oleh penelitian Fitriah \& Sudirjo (2016) dan Nurfadillah (2011) namun dengan saham yang berbeda.

ROA dijadikan pendekatan rasio keuangan dalam penelitian ini dikarenakan ROA merupakan indikator dalam menghasilkan keuntungan bagi perusahaan sehingga secara tidak langsung berdampak pada harga saham. Pada saham telekomunikasi berdasarkan periode pengamatan penelitian, harga saham tidak terpengaruh oleh besarnya ROA. Fitriah \& Sudirjo (2016) menunjukkan hasil yang tidak sama, yaitu harga saham mampu dipengaruhi oleh ROA. Hasil yang cukup berbeda ini dikarenakan pilhan saham yang digunakan dan periode pengamatan dalam pengambilan data. Hasil tidak mampu dipengaruhinya harga saham oleh ROA ini, juga ditemukan oleh Egam, Ilat, \& Pangerapan (2017) dengan menggunakan saham LQ45.

Untuk menguji pengaruh secara simultan akan dibantu dengan menggunakan uji F. Uji F ini akan disajikan dalam Tabel 3. Tabel 3 menunjukkan nilai sig untuk uji F. Nilai sig. F yang didapatkan sebesar 0,002. Jika dibandingkan dengan nilai sig. 0,05 maka akan didapatkan nilai sig F lebih kecil dari 0,05 $(0,002<0,05)$ sehingga berdasarkan hasil tersebut didapatkan harga saham telekomunikasi secara bersama-sama dapat dipengaruhi oleh variabel CR, EPS, DER dan ROA secara signifikan.

Tabel 3. ANOVA

ANOVA $^{a}$

\begin{tabular}{clccccc}
\hline & Model & Sum of Squares & df & Mean Square & $F$ & Sig. \\
\hline 1 & Regression & 57.817 & 4 & 14.454 & 6.113 & $.002^{b}$ \\
& Residual & 47.288 & 20 & 2.364 & & \\
& Total & 105.106 & 24 & & & \\
\hline
\end{tabular}

a. Dependent Variable: Price

b. Predictors: (Constant), ROA, EPS, DER, CR

\section{KESIMPULAN}

Penilaian harga saham menggunakan pendekatan rasio keuangan dengan menitikberatkan pada saham telekomunikasi dengan menggunakan periode 2014-2018 didapatkan hasil analisis bahwa dengan rasio keuangan CR, EPS, DER dan ROA hanya satu variabel yang tercatat memiliki kemampuan dalam mempengaruhi harga saham telekomunikasi secara parsial yaitu CR. Hal ini sekaligus menunjukkan bahwa harga saham telekomunikasi tidak dapat dipengaruhi oleh variabel EPS, DER dan ROA. Namun jika diuji secara simultan, CR, EPS, DER dan ROA tercatat memiliki pengaruh secara bersama-sama (simultan) kepada harga saham telekomunikasi pada 2014-2018. Implikasi hasil penelitian yang telah didapatkan ini mampu memberikan gambaran dan pertimbangan bagi investor dalam keputusan pembelian terutama untuk saham telekomunikasi. Analisis rasio keuangan yang cermat oleh investor sebelum pengambilan keputusan pembelian 


\section{PERFORMANCE}

Jurnal Personalia, Financial, Operasional,

Marketing dau Sistem Informasi

Performance. Volume 27 Nomor 1 Tahun 2020, 21-29

akan membantu investor dalam menginvestasikan dana yang dimiliki dengan tepat sehingga mendapat return yang menguntungkan.

Penelitian masih memiliki keterbatasan yaitu rasio keuangan yang dipilih hanya terdiri dari empat rasio keuangan. Hal ini belum menggambarkan secara keseluruhan pengaruh rasio keuangan terhadap perkembangan harga saham telekomunikasi, karena masih ada beberapa rasio keuangan lain yang dapat dijadikan variabel dalam mempengaruhi pergerakan harga saham. Berdasarkan hal tersebut. maka dapat disarankan meneliti dengan menambahkan rasio keuangan yang lain untuk melihat pengaruhnya terhadap harga saham terutama untuk saham telekomunikasi yang tercatat di BEI.

\section{DAFTAR PUSTAKA}

Agustina, \& Sumartio, F. (2014). Analisa Faktor-Faktor Yang Mempengaruhi Pergerakan Harga Saham Pada Perusahaan Pertambangan. Jurnal Wira Ekonomi Mikroskil, 4(1), 51-61.

Anung, M. . R., Hidayat, R. R., \& Sulasmiati, S. (2016). Penggunaan Analisis Fundamental Pendekatan Price Earning Ratio (PER) Dalam Pengambilan Keputusan Investasi Saham ( Studi pada Saham Emiten yang Terdaftar dalam Jakarta Islamic Index Periode 2012- 2015 ). Jurnal Administrasi Bisnis (JAB), 40(2), 169-176.

Bagiana, I. K., Putra, I. G. C., \& Sunarsih, N. M. (2016). Pengaruh Kinerja Keuangan, Ukuran Perusahaan Dan Investment Opportunity Set Terhadap Kebijakan Dividen. Seminar Nasional, (11), 580-591.

Baresa, S., Bogdan, S., \& Ivanovic, Z. (2013). Strategy of Stock Valuation by Fundamental Analysis. Journal of Economics, 4(1), 45-51.

Basuki, A. T., \& Prawoto, N. (2016). Analisis Regresi Dalam Penelitian Ekonomi \& Bisnis (Dilengkapi Aplikasi SPSS \& EVIEWS). Jakarta: PT RajaGrafindo Persada.

Dwialesi, J. B., \& Darmayanti, N. P. A. (2016). Pengaruh Faktor-Faktor Fundamental Terhadap Return Saham Indeks Kompas 100. E-Journal Management Unud, 5(9), 2544-2572.

Egam, G. E. Y., Ilat, V., \& Pangerapan, S. (2017). Pengaruh Return On Asset (ROA), Return On Equity (ROE), Net Profit Margin (NPM), dan Earning Per Share (EPS) Terhadap Harga Saham Perusahaan Yang Tergabung Dalam LQ45 Di Bursa Efek Indonesia Tahun 2013-2015. Jurnal EMBA, 5(1), 105-114.

Erica, D. (2018). Analisa Rasio Laporan Keuangan Untuk Menilai Kinerja Perusahaan PT Kino Indonesia Tbk. Jurnal Ecodemica, 2(1), 12-20. Retrieved from http://ejournal.bsi.ac.id/ejurnal/index.php/moneter/article/view/1192

Fitriah, \& Sudirjo, F. (2016). Pengaruh Analisis Rasio Keuangan, Rasio Pasar dan Kebijakan Deviden Terhadap Harga Saham. Jurnal IImiah UNTAG Semarang, 5(2), 1-16.

Hadiansyah, N., \& Gunawan, B. (2017). Analisis Makro Ekonomi dan Fundamental Terhadap Harga Saham Perbankan Yang Terdaftar Pada Indeks LQ 45 Periode 2009-2013. Jurnal Ekonomi Bisnis, 22(1), 26-36.

Khairani, I. (2016). Pengaruh Earning Per Share (EPS) dan Deviden Per Share Terhadap Harga 
Jurnal Personalia, Financial, Operasional,

Marketing dau Sistern Informasi

Performance. Volume 27 Nomor 1 Tahun 2020, 21-29

Saham Perusahaan Pertambangan Yang Terdaftar Di Bursa Efek Indonesia (BEI) Tahun 20112013. Jurnal Manajemen Dan Keuangan Unsam, 5(1), 566-572.

Megawati, S. B. (2018). Pengaruh Rasio Keuangan Terhadap Harga Saham Pada Perusahaan Telekomunikasi Yang Terdaftar Di Bursa Efek Indonesia Tahun 2012-2016. Pendidikan Ekonomi, 7(5), 418-429.

Nurfadillah, M. (2011). Analisis Pengaruh Earning Per Share, Debt To Equity Ratio Dan Return On Equity Terhadap Harga Saham PT Unilever Indonesia Tbk. Jurnal Manajemen Dan Akuntansi, 12(1), 45-50.

Pratama, A., \& Erawati, T. (2014). Pengaruh Current Ratio, Debt To Equity Ratio, Return On Equity, Net Profit Margin dan Earning Per Share Terhadap Harga Saham (Study Kasus Pada Perusahaan Manufaktur Yang Terdaftar Di Bursa Efek Indonesia Periode 2008-2011). Jurnal Akuntansi, 2(1), 1-10.

Pratama, C. A., Azizah, D. F., \& Nurlaily, F. (2019). Pengaruh Return On Equity (ROE), Earning Per Share (EPS), Current Ratio (CR) dan DEbt To Equity Ratio (DER) Terhadap Harga Saham (Studi pada Perusahaan Jakarta Islamic Index yang Terdaftar di Bursa Efek Indonesia Tahun 20142017). Jurnal Administrasi Bisnis (JAB), 66(1), 10-17.

Rahmadewi, P. W., \& Abundanti, N. (2018). Pengaruh EPS, PER, CR Dan ROE Terhadap Harga Saham Di Bursa Efek Indonesia. E-Jurnal Manajemen Universitas Udayana, 7(4), 2106-2133. https://doi.org/10.24843/ejmunud.2018.v07.i04.p14

Tanjung, R. S., Suhadak, \& Sudjana, N. (2013). Faktor Fundamental Perusahaan Yang Berpengaruh Terhadap Harga Saham (Studi pada Perusahaan Food and Beverages di Bursa Efek Indonesia periode 2009-2011). Jurnal Administrasi Bisnis (JAB), 2(1), 193-202.

Thrisye, R. Y., \& Simu, N. (2013). Analisis Pengaruh Rasio Keuangan Terhadap Return Saham BUMN Sektor Pertambangan Periode 2007-2010. Jurnal IImiah Akuntansi Dan Bisnis, 8(2), $75-81$.

Wafi, A. S., Hassan, H., \& Mabrouk, A. (2015). Fundamental Analysis Models in Financial Markets - Review Study. Procedia Economics and Finance, 30(15), 939-947. https://doi.org/10.1016/S2212-5671(15)01344-1 